K. Simakov,

PhD (Economics), Associate Professor, ORCID 0000-0003-0094-2930, e-mail: irinas.dgma@gmail.com,

S. Chernyshova, ORCID 0000-0003-4229-3879, Donbass State Engineering Academy, Kramatorsk

\title{
IMPROVING THE MANAGEMENT ACCOUNTING SYSTEM THROUGH STRATEGIC BUDGETING IN AN INDUSTRIAL ENTERPRISE
}

Formulation of the problem. Management accounting as an integrated system of information processing and preparation for domestic users plays an important role in the economy of most foreign and domestic enterprises. Under this common term today means a special system within the corporate management of costs and working capital in order to optimize the use of capital, increase profitability, improve financial and non-financial performance of the enterprise and, of course, gain market leadership. In modern conditions there is an objective need for new approaches to the content and organization of accounting for management.

There is a need for constant control of income and expenses, as well as cash flow, which is difficult to do without planning. To do this, budgeting is introduced at the enterprise and used in management accounting. However, for many budgets mean only plans for sales, production, use of material and labor resources or in general the calculation of individual indicators, which significantly narrows the possibilities of budgeting, because for management it is also advisable to take into account the implementation of strategy and resource allocation. This justifies the relevance of this study.

Analysis of recent research and publications. Problems of development of management accounting were studied by such domestic and foreign scientists as: A. Upcherch, S. Golov, R. Harrison, K. Drury, Z. Zadorozhniy, L. Napadovska, M. Pushkar, V. Rudnytsky, I. Farion, T. Pisarenko, O. Fomina, C. Horngren, N. Chumachenko, J. Shank, V. Govindarajan, N. Shlyago, R. Anthony and others. Today, among domestic and foreign scholars and practitioners there is no consensus on the definition of the concept of "management accounting", and hence - many misunderstandings.

Theoretical and practical aspects of budgeting were considered by such scholars as T. Pozhuyeva, A. Tkachenko, N. Rudik, N. Ishchenko and others. However, despite the development of the basics of budgeting and the formation of its individual elements for financial management in business, it becomes necessary to improve budgeting with a focus on strategic goals and taking into account changes in business, which increases the relevance of this study.

The purpose of the article is to determine the advantages and problems of strategic budgeting in the management accounting system of an industrial enterprise.

Presentation of the main research material. Today, the problem of using management accounting to improve the efficiency of enterprise management is becoming increasingly important. At the same time, it is necessary to note the special importance of solving this issue for public and private enterprises and organizations of the Ukrainian economy. This is due to the lack of a unified methodological framework and recommendations for the organization of management accounting in some sectors of the domestic economy, and in general the peculiarities of the formation and development of management accounting in Ukraine.

The program of accounting reform in Ukraine provides for the provision of business entities the opportunity to determine the system and forms of internal economic (management) accounting. According to the Law of Ukraine "On Accounting and Financial Reporting in Ukraine" dated 16.07.1999 № 996 internal (management) accounting is submitted as "... system of processing and preparation of information about the activities of the enterprise for internal users in the process of enterprise management" [1].

According to N. Shlyago, in countries with a traditional market economy, even if provisions are developed for the organization and maintenance of management accounting, as, for example, in the United States, they are of a recommendatory nature and are developed by professional organizations [2, p. 33].

The active introduction of management accounting in Ukraine is hindered primarily by the inadequate attitude to it in the senior management of large enterprises. This is largely due to the perception of management accounting as part of the accounting information required for external financial analysis [3, p. 47].

Management accounting is designed to provide reliable and complete information that is necessary for making correct and effective management decisions of the enterprise. But in practice, the leaders of Ukrainian companies still do not have a clear understanding of this type of accounting, which is probably the main problem in the process of setting up a management accounting system [4].

As practice shows, managers of Ukrainian enterprises, usually familiar with the general theoretical 
foundations of management accounting, have no idea how to apply them in practice.

Moreover, there is an inadequate attitude to the management accounting of senior management of large enterprises, which perceive it as part of the accounting information required for external financial analysis. But at the present stage of its development, management accounting in the enterprise is not just an accounting system, but also begins to become the main key core of the entire management system of the organization as a whole. In other words, modern management accounting is an integrated management system of the enterprise, which forms and provides information about the results of activities - financial, time, quality, value, etc. - as the whole enterprise and its individual components - departments, employees, projects etc. Taking into account the above, we can identify the following basic elements that determine the overall information system of management accounting - responsibility centers, business processes, regulations, results and evaluation indicators (Fig. 1).

\begin{tabular}{|c|c|c|c|}
\hline Responsibility centers & Business processes & Regulations and standards & $\begin{array}{l}\text { Results and evaluation } \\
\text { indicators }\end{array}$ \\
\hline $\begin{array}{l}\text { - Profit centers; } \\
\text { - Cost centers; } \\
\text { - Financial accounting } \\
\text { centers; } \\
\text { - Units; } \\
\text { - Employees; } \\
\text { - Other }\end{array}$ & $\begin{array}{l}\text { - Finances; } \\
\text { - Accounting; } \\
\text { - Marketing; } \\
\text { - Staff; } \\
\text { - Auxiliary processes }\end{array}$ & $\begin{array}{l}\text { - International standarts; } \\
\text { - National standarts; } \\
\text { - Corporate standarts; } \\
\text { - Regulations; } \\
\text { - Position }\end{array}$ & $\begin{array}{l}\text { - Financial; } \\
\text { - Valuable; } \\
\text { - Natural; } \\
\text { - Quantitative; } \\
\text { - Quality; } \\
\text { - Temporary }\end{array}$ \\
\hline
\end{tabular}

Fig. 1. The main elements of the management accounting system

(formed by the authors based on the source [5])

Management actions taken by the management of an industrial enterprise should lead to the solution of the following tasks:

1. Redistribution of working capital in favor of goods with high demand and margins.

2. Determining the maximum margin at which it is possible to maintain a stable level of sales.

3. Timely redistribution of working capital at the beginning and end of the seasonal period.

4. Making decisions on closing low-profitable outlets that have no prospects for growth in production.

5. Purchase of new equipment to expand the product range.

6. Determining the causes of low sales.

7. Control of mutual settlements with counterparties.

8. Evaluation of the effectiveness of investments in marketing research, trade automation and purchase of new equipment.

9. Defining centers of responsibility for work processes.

10. Control of return on assets, working capital, fixed assets and other indicators of resource efficiency.

These tasks are easily solved with the help of management accounting tools.

As a result, the actions of managers become reasonable, and their result - more predictable. Effective solution of the above tasks can be achieved through complexity in the construction and operation of management accounting, which is provided by the use of the following principles of formation, development, implementation and use of management accounting system (Table 1).

Table 1

Principles of formation, development, implementation and use of the management at an industrial enterprise (formed by the authors based on the source [5])

\begin{tabular}{|c|l|}
\hline No. & \multicolumn{1}{c|}{ Principles of formation of the management accounting system } \\
\hline 1 & $\begin{array}{l}\text { Structuring the activities of the enterprise as a set of interconnected and continuous business processes - groups of op- } \\
\text { erations aimed at obtaining a certain end result }\end{array}$ \\
\hline 2 & $\begin{array}{l}\text { Ability to constantly assess the projected, planned and actual results in the system of management accounting of financial } \\
\text { and economic activities of the organization as an enterprise as a whole and in terms of business processes, centers of } \\
\text { responsibility - departments, employees, projects, etc. }\end{array}$ \\
\hline 3 & $\begin{array}{l}\text { Mandatory regulation of execution and operational accounting of business processes results on the basis of relevant } \\
\text { external and internal standards - regulations of international, national, industry or corporate level, which determine the } \\
\text { procedure, timing of operations, results and quality of their implementation and realization }\end{array}$ \\
\hline 4 & $\begin{array}{l}\text { Complexity and analytical use for management accounting of results and characteristics of their evaluation indicators, } \\
\text { which ensure their representativeness and balance in relation to the development strategies, goals and objectives of the } \\
\text { organization as a whole }\end{array}$ \\
\hline
\end{tabular}

The enterprise management system must be ready for future changes in the external environment of the enterprise, ie by improving the efficiency of resources, ensuring a balance of interests with the environment, or strengthening or maintaining its market position to maintain product competitiveness, ensure the adaptability of the enterprise system to factors of influence of the external environment in order to ensure the economic security of the enterprise. This situation led to the search and use of effective means of survival, one of which was 
the budget method of management, which showed in a competitive environment its advantages over other methods.

The budget management system is increasingly seen as an effective technology that can solve the following tasks: 1) creating a basis for effective management decisions; 2) increasing the efficiency of use of own resources, assets of the enterprise; 3) creating an opportunity to assess the investment attractiveness of certain activities; 4) the validity of the allocation of financial resources in certain areas; 5) ensuring "financial transparency"; 6) increasing the level of financial discipline, stimulating the effective work of units; 7) monitoring the financial efficiency of divisions and types of business; 8) control over changes in the financial situation, increase financial stability, increase the stability of the financial condition of the enterprise. The concept of budgeting organization is a system of views on the organization of the budgeting process, its concept and theoretical basis. The concept should (Fig. 2): minimize the amount of transaction costs; clearly define the levels of management decisions; ensure the flexibility of the budget system.

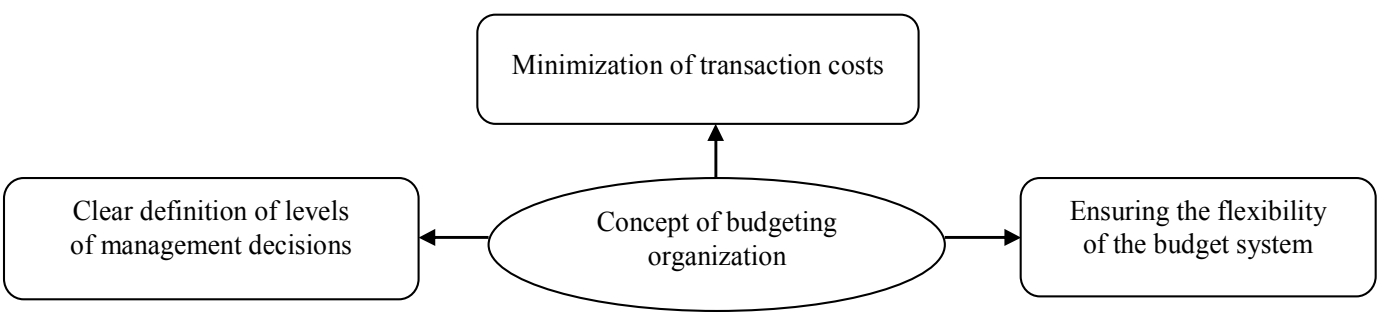

Fig. 2. Advantages of the concept of budgeting organization in an industrial enterprise (formed by the authors based on the source [6])

Budget management should be strict - the heads of services and departments of the industrial enterprise must, on the one hand, be strictly guided in their activities by the approved production and economic plan and budget. However, on the other hand, the regulations of the planning and budget process should leave room for timely adjustment and making optimal decisions on the implementation of a particular project in the interests of the enterprise, ie to be as flexible as possible. The key link in the organization of the process of development and implementation of budgets of an industrial enterprise is the correct distribution of powers and responsibilities in the system of planning and budget management.

For an industrial enterprise there is a need to create a budget committee - a permanent coordinating body for budget planning. The concept of the system of organization of budgeting of the industrial enterprise should contain: positioning of tools of budgeting in system (interrelation of operational budgets with the consolidated budgetary forms); determination of levels of managerial decision-making; establishing the relationship of operational, accounting and management accounting with the budgeting system; assessment of the impact of external information on the company on management decisions.

The scheme of making strategic and operational management decisions within the concept of budgeting in an industrial enterprise can be presented in the form of a developed model of information flows with feedback (Fig. 3).

Thus, the scheme of information flows within the budgeting concept meets the main goal - to increase the economic efficiency of management decisions by coordinating the activities of all structural units of the enterprise, aimed at achieving quantitatively and qualitatively defined end result and strengthening financial stability.
The development of management techniques and changing environmental conditions requires increasing the flexibility of the budgeting system, increasing the role of strategic objectives, as well as improving its tools. In the traditional sense, the budgeting process is a forecast of enterprise development for the future, based on a retrospective analysis of the financial condition of the enterprise and assessment of the impact of various factors on the main indicators of its activities. However, the dynamically developing economic relations in Ukraine require new forms of enterprise management, closely related to its strategy.

The Balanced Scorecard (MAS) technology emerged as a response to the limited methods of managing businesses using only financial metrics. For all their importance, they are insufficient to determine how effectively the company or its individual units operate. First, because these indicators, in fact, reflect the efficiency of the enterprise in the past, not allowing to diagnose and eliminate emerging problems in "real time". Secondly, the use of only financial indicators does not allow to bring the strategic goals of the company to all employees and does not allow them to determine their role in achieving these goals, because not all employees are involved in their formation. The lack of connection between the budgeting system and the company's strategy is the reason for ineffective motivation of department heads and their employees to achieve strategic goals.

As a rule, after setting target values in strategic maps for business deviations, which are inevitable, the cost of measures is reduced, but the target values of a balanced scorecard are not always revised, which leads to their non-compliance, and as a result - to discredit the idea effective strategic management on a balanced scorecard. Integration into a single budget and a balanced scorecard can eliminate these problems. In the 


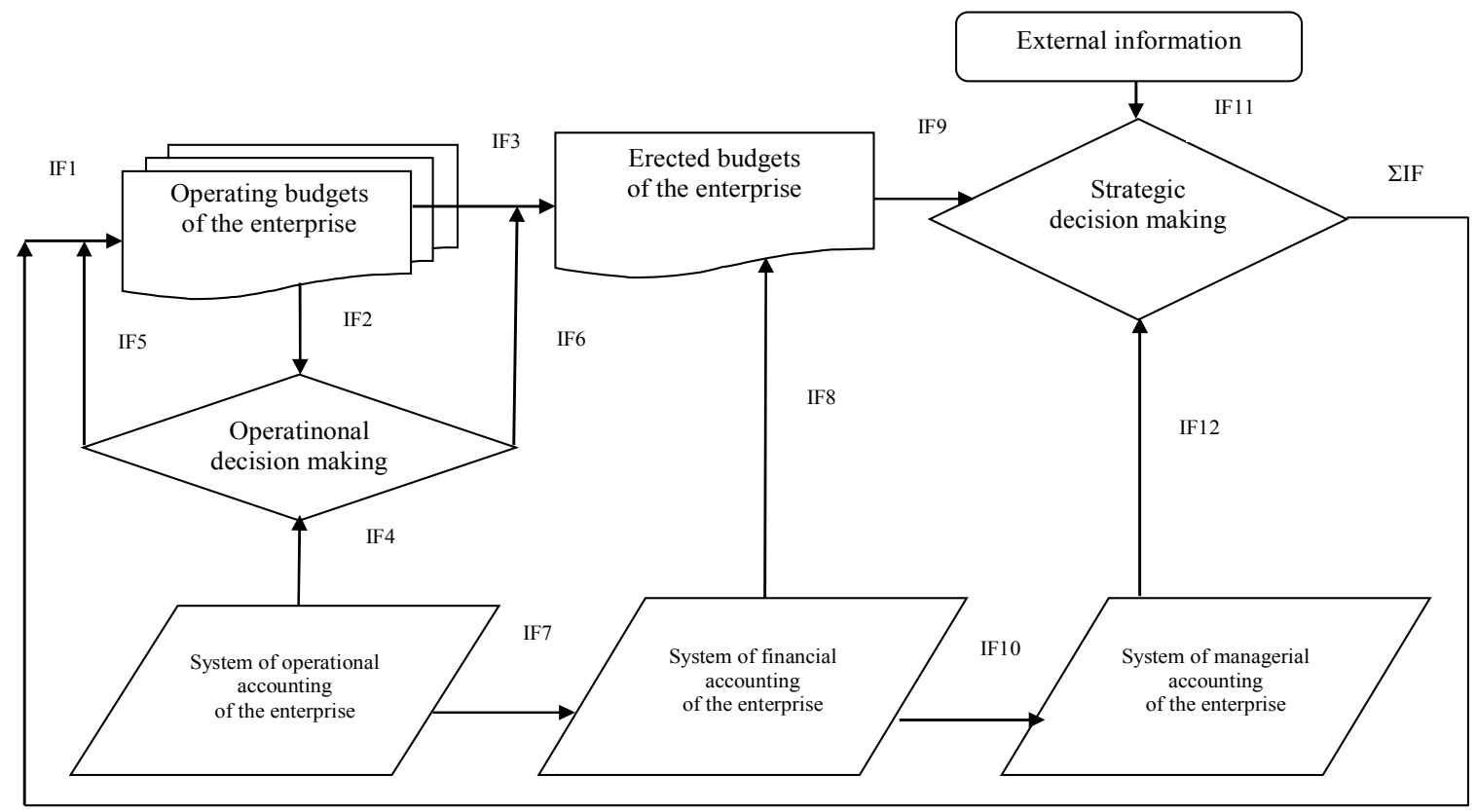

Fig. 3. The scheme of management decisions within the concept of budgeting (formed by the authors based on the source [6])

Symbols of information flows (IF) should be interpreted as:

IF1 - input information flow of the system - when implementing budgeting is equal to the parameters of forecast sales of the enterprise (planning from the sales budget), in subsequent budget cycles equal to the output total information flow of the system (GIP); IF2 - information flow of the system of operating budgets of the enterprise (formed by the transfer of budget tasks to the places - in the structural units of the enterprise); forms);

IF3 - information flow of the system of operating budgets of the enterprise (formed by filling in the consolidated budget

IF4 - information flow of the operational accounting system of the enterprise (formed as the implementation of the planned task by structural units);

IF5, IF6 - information flows generated on the basis of the plan-fact analysis of the implementation of operating budgets. IF5 is designed to adjust the planned task in the appropriate operational forms (flexible planning) in case of significant deviations in fact; IF6 - makes adjustments directly to the consolidated budget forms (in the absence of flexible planning practices);

IF7 - information flow of primary information of financial accounting of the enterprise (allows to generate consolidated reporting forms of accounting);

IF8 - information flow of financial accounting of the enterprise (allows to carry out the plan-fact analysis of the consolidated forms of budgets);

IF9 - information flow of the budgeting system (generates consolidated budget information for management decisions);

IF10 - information flow of financial accounting of the enterprise (in terms of the need for actual accounting information of the management accounting system);

IF11 - information flow of information external to the enterprise (allows you to adjust the internal management decisions taking into account the degree of influence and forecast of the external environment);

IF12 - information flow of the management accounting system of the enterprise (production, marketing, other information for decision making);

$\Sigma \mathrm{IF}$ - output information flow of the system (contains key parameters for the new budget cycle).

Table 2 shows how the implementation of different control functions in a single system manifests a synergistic effect [6].

The system of strategic budget management allows to solve the following tasks:

- establishing the relationship between planning and monitoring the implementation of strategic and tactical plans of the enterprise;

- ensuring the consistency of the plans of all departments in the enterprise and their focus on achieving common goals;

- assessment and interdependent management of all aspects of the enterprise;
- strengthening of financial discipline and subordination of interests of separate structural divisions to interests of the enterprise as a whole by means of management on deviations based on comparison of the projected and actual indicators of activity of the enterprise for the reporting period;

- the ability to calculate various plans without involving additional resources;

- creating a basis for a sound system of staff motivation by linking it to the system of financial indicators [6].

To organically combine strategically important, mostly non-financial goals of the enterprise with a system of short-term financial indicators, it is necessary to 
supplement the horizontal approach to managing the system of vertical integration in the budgeting process. Thus, the goals and indicators in the strategic compo- nent of the industrial enterprise will find financial justification by detailing the goals and indicators of operating budgets of the enterprise.

Table 2

Syneogenetic effect of combining balanced scorecard and budgeting [6]

\begin{tabular}{|c|c|c|c|}
\hline Management functions & Traditional budgeting system & Balanced scorecard & $\begin{array}{c}\text { Strategic } \\
\text { budgeting system }\end{array}$ \\
\hline Planning & $\begin{array}{l}\text { Distribution of enterprise resources for } \\
\text { the current period }\end{array}$ & Specification of strategic goals & $\begin{array}{l}\text { Plan goal and resources to achieve them } \\
\text { in quantitative terms }\end{array}$ \\
\hline Coordination & $\begin{array}{l}\text { Firm connection of budgets of the cen- } \\
\text { ters of financial responsibility and the } \\
\text { budget of the enterprise }\end{array}$ & $\begin{array}{l}\text { Causal investigative connection of } \\
\text { a balanced scorecard of indicators of } \\
\text { divisions and balanced scorecard of } \\
\text { the enterprise as a whole }\end{array}$ & $\begin{array}{l}\text { Interdependent plans of indicators on di- } \\
\text { visions and support of the enterprise as a } \\
\text { whole }\end{array}$ \\
\hline Motivation and control & $\begin{array}{l}\text { Saving of budgets of the centers of fi- } \\
\text { nancial responsibility }\end{array}$ & $\begin{array}{l}\text { Achieving the target values of the } \\
\text { balanced scorecard unit }\end{array}$ & $\begin{array}{l}\text { Achieving the target values of the ba- } \\
\text { lanced scorecard of the centers of financial } \\
\text { responsibility while saving budgets }\end{array}$ \\
\hline
\end{tabular}

If the process of setting long-term goals of the enterprise in the long-term development program is performed satisfactorily, then the operational budget will be to transform the plan of the first year of the period into the current operating budget, which will fully meet the strategic goals and indicators of the enterprise [6].

The mechanism of transformation of strategic goals of an industrial enterprise with the help of strategic maps into a system of budgets is presented in Fig. 4.

Budgeting as a management technology involves determining the levels of budget consolidation that correspond to the levels of the management hierarchy. Budgeting acts as a link between the accounting process of the enterprise and its management, being, on the one hand, the information base of management accounting, and on the other - reflects its state in the future. Management accounting, in turn, serves as an information base for making management decisions based on data provided by the budgets of the enterprise.

The budget is an operational financial plan of the enterprise, drawn up for the next period (year) in physical and monetary terms, which reflects the receipt (income) and expenditure of funds and covers all areas of economic activity of the enterprise. Non-financial indicators of a balanced scorecard are the starting point of new management, whose role is to transform the concept and strategy of the enterprise in the plane of shortterm financial goals and indicators that form the basis of the budgeting process.

The synergy of all non-financial components allows to reconcile financial strategic goals with the annual distribution of resources through the budgets of the enterprise. Strategic budgets of an industrial enterprise allow not only to calculate the necessary costs of the enterprise for the implementation of strategic initiatives, but also to make a forecast of costs for future periods with a cumulative result. The overestimation of budget indicators takes place in case of impossibility to identify the exact ratio between the required resource costs and the financial result.

In general, it can be noted that the use of strategic budgets of an industrial enterprise makes it possible to improve the quality of current and strategic planning at the enterprise, to make it an effective element of the management system.
Conclusions. Summarizing the results of the study, it should be noted that modern management accounting is an integrated system of enterprise management, which forms and provides information about the results of activities - financial, time, quality, cost, etc. - as the whole enterprise and its individual components - structural divisions, employees, projects, etc.

The proposed comprehensive approach to improving the management accounting system through strategic budgeting, provides an opportunity to improve the quality of current and strategic planning in the enterprise, to make it an effective element of the management system. Unlike traditional budget management, strategic budgeting focuses mainly on non-financial indicators, which are aimed at achieving strategic goals through the formation of non-financial strategic budgets.

Based on the actual data presented in the forms of strategic reporting, an assessment of the implementation of budget indicators of the enterprise is made, followed by analysis of deviations of actually achieved results from those planned in the budget, significant changes which lead to budget revision. Timely response to deviations of strategic budget indicators effectively provides flexible budgeting, which allows to make adjustments to their values by choosing the best budget option, which is based on the results of retrospective analysis of the financial condition of the enterprise and assessment of its development forecast.

\section{Literature}

1. Про бухгалтерський облік і фінансову звітність в Україні: Закон України від 16.07.1999 № 996XI. URL: http://zakon. rada.gov.ua/laws/show/996-14. 2. Шляго Н. Н. Управленческий учет: рудименты прошлого в осознании настоящего. СПб. : Изд-во Политехн. ун-та, 2007. 160 с. 3. Воронова Е. Системы управленческого учета: развитие в условиях новых методов управления. Проблемь теории и практики управления. 2007. № 9. С. 45-52. 4. Довжик О. О. Роль управлінського обліку та проблеми його впровадження на підприємствах. Вісник Полтавської державної аграрної академії. 2012. № 2. С. 174-179. 5. Энтони Р., Рис Дж. Учет: ситуации и примеры. Москва: Финансы и статистика, 1993. 557 с. 6. Хруцкий В. Е., Сизо- 


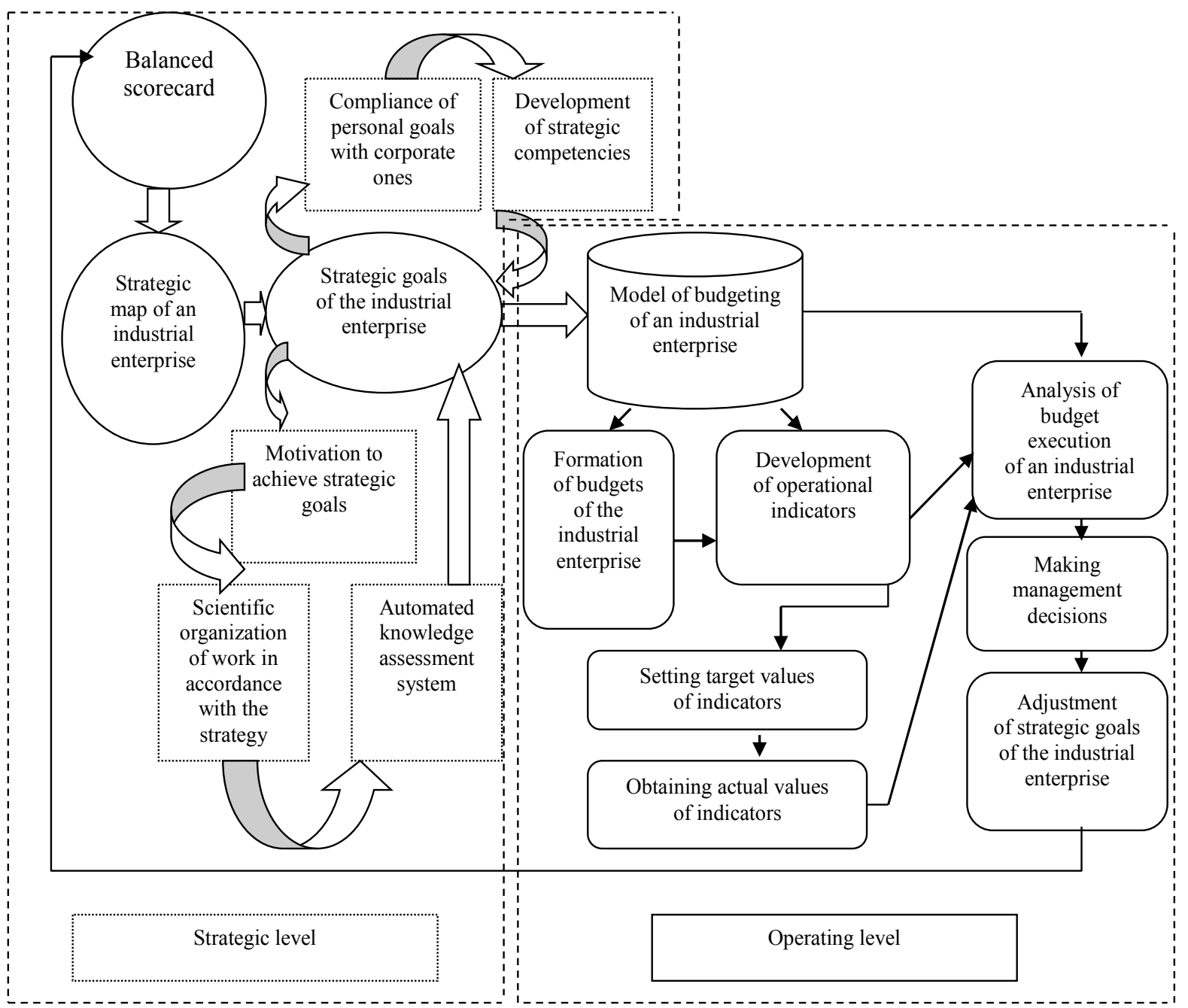

Fig. 4. The mechanism of transformation of strategic goals of an industrial enterprise with the help of strategic maps into a system of budgets

(formed by the authors based on the source [7])

ва Т. В., Гамаюнов В. В. Внутрифирменное бюджетирование: настольная книга по постановке финансового планирования. Москва : Финансы и статистика, 2002. 400 с. 7. Каплан Р., Нортон Д. Стратегические карты. Трансформация нематериальных активов в материальные результаты : пер. с англ. Москва : ЗАО «Олимпбизнес», 2005. 512 с. 8. Чибісов Ю. В. Бухгалтерський облік виробничої діяльності в системі бюджетування: теоретико-методичні основи : автореф. дис. на здобуття наук. ступеня канд. екон. наук : спец. 08.00.09/ Держ. акад. статистики, обліку та аудиту Держкомстату України. Київ, 2008. 20 с. 9. Мельник О. Г. Бюджетування в системі управління підприємством : автореф. дис. на здобуття наук. ступеня канд. екон. наук : спец. 08.06.01 / Нац. ун-т "Львів. політехніка". Львів, 2004. 25 с. 10. Нападовська Л. В. Базові принципи управлінського обліку. Актуальні проблеми економіки. 2013. № 1. С. 173-181. 11. Жуков С. А. Роль бюджетування в системі стратегічного управління людським капіталом промислового підприємства. Економічний вісник Донбасу. 2017. № 2 (48). С. 214-219.

\section{References}

1. Pro bukhhalterskyi oblik i finansovu zvitnist v Ukraini: Zakon Ukrainy vid 16.07.1999 № 996-XI [On Accounting and Financial Reporting in Ukraine: Law of Ukraine of July 16, 1999 № 996-XI]. Retrieved from http: //zakon. rada.gov.ua/laws/show/996-14 [in Ukrainian].

2. Shlyago, N. N. (2007). Management accounting: the rudiments of the past in the awareness of the present. $\mathrm{SPb}$., Publishing house of the Polytechnic University [in Russian].

3. Voronova, E. (2007). Management accounting systems: development under new management methods. Problems of theory and practice of management, 9, pp. 4552 [in Russian].

4. Dovzhyk, O. O. (2012). Rol upravlinskoho obliku ta problemy yoho vprovadzhennia na pidpryiemstvakh [The role of management accounting and problems of its implementation at enterprises]. Visnyk Poltavskoi derzhavnoi ahrarnoi akademii - Bulletin of the Poltava State Agrarian Academy, 2, pp. 174-179 [in Russian].

5. Anthony, R., Rhys, J. (1993). Accounting: situations and examples. Moscow, Finance and Statistics [in Russian]. 
6. Khrutskiy, V. E., Sizova, T. V., Gamayunov, V. V. (2002). Intrafirm budgeting: a handbook on financial planning. Moscow, Finance and Statistics [in Russian].

7. Kaplan, R., Norton, D. (2005). Strategic maps. Transformation of intangible assets into tangible results. Trans. from English. Moscow, ZAO "Olimp-business" [in Russian].

8. Chybisov, Yu. V. (2008). Bukhhalterskyi oblik vyrobnychoi diialnosti $\mathrm{v}$ systemi biudzhetuvannia: teoretyko-metodychni osnovy [Accounting Obligation of Verobnichoi Activity in the Budget System: Theoretical and Methodological Foundations]. Extended abstract of candidate's thesis. Kyiv, State Academy of Statistics, Audit Office of the State Statistics Committee of Ukraine [in Ukrainian].

9. Melnyk, O. H. (2004). Biudzhetuvannia v systemi upravlinnia pidpryiemstvom [Budgeting in the enterprise management system]. Extended abstract of candidate's thesis. Lviv, National Lviv Polytechnic University [in Ukrainian].

10. Napadovska, L. V. (2013). Bazovi pryntsypy upravlinskoho obliku [Basic principles of management accounting]. Aktualni problemy ekonomiky - Current economic problems, 1, pp. 173-181 [in Ukrainian].

11. Zhukov, S. A. (2017). Rol biudzhetuvannia v systemi stratehichnoho upravlinnia liudskym kapitalom promyslovoho pidpryiemstva [Role of budgeting in the system of strategic management of the human capital of an in-dustrial enterprise]. Ekonomichnyi visnyk Donbasu Economic Herald of the Donbas, 2 (48), pp. 214-219 [in Ukrainian].

Сімаков К. І., Чернишова С. О. Удосконалення системи управлінського обліку за допомогою стратегічного бюджетування на промисловому підприсмстві

У статті визначено принципи формування, розробки, впровадження та використання системи управлінського обліку на промисловому підприємстві. Наведено схему прийняття управлінських рішень у рамках концепції бюджетування. Обгрунтовано необхідність визначення ролі бюджетування в системі управлінського обліку промислового підприємства. Досліджено взаємозв'язок між процесом складання бюджету й стратегічними цілями промислового підприємства за допомогою збалансованої системи показників, яка надає всебічну оцінку стратегічних показників підприємства шляхом інтеграції його стратегічних цілей і тактичних можливостей. Представлено механізм трансформації стратегічних цілей промислового підприємства на операційний рівень за допомогою складових збалансованої системи показників. Доведено, що використання стратегічних бюджетів у системі управлінського обліку дає можливість підвищувати якість поточного й стратегічного планування на підприємстві, poбити його ефективним елементом системи управління.

Ключові слова: бюджетування, промислове підприємство, бюджет, управлінський облік, планування, збалансована система показників, стратегічні цілі, стратегічне бюджетування.
Simakov K., Chernyshova S. Improving the Management Accounting System through Strategic Budgeting in an Industrial Enterprise

The article defines the principles of formation, development, implementation and use of management accoun ting at an industrial enterprise. The scheme of making managerial decisions within the concept of budgeting is given. The necessity of determining the role of budgeting in the system of management accounting of an industrial enterprise is substantiated. The relationship between the budgeting process and the strategic goals of the industrial enterprise with the help of a balanced system of indicators, which provides a comprehensive assessment of the strategic indicators of the enterprise by integrating its strategic goals and tactical capabilities.

The mechanism of transformation of strategic goals of an industrial enterprise to the operational level with the help of components of a balanced system of indicators is presented. It is proved that the use of strategic budgets in the system of management accounting makes it possible to improve the quality of current and strategic planning in the enterprise, to make it an effective element of the management system.

Keywords: budgeting, industrial enterprise, budget, management accounting, planning, balanced scorecard, strategic goals, strategic budgeting.

Сімаков К. И., Чернышова С. А. Совершенствование системы управленческого учета с помощью стратегического бюджетирования на промышленном предприятии

В статье определены принципы формирования, разработки, внедрения и использования системы управленческого учета на промышленном предприятии. Приведена схема принятия управленческих решений в рамках концепции бюджетирования. Обоснована необходимость определения роли бюджетирования в системе управленческого учета промышленного предприятия. Исследована взаимосвязь между процессом составления бюджета и стратегическими целями промышленного предприятия с помощью сбалансированной системы показателей, которая предоставляет всестороннюю оценку стратегических показателей предприятия путем интеграции его стратегических целей и тактических возможностей. Представлен механизм трансформации стратегических целей промышленного предприятия на операционный уровень с помощью составляющих сбалансированной системы показателей. Доказано, что использование стратегических бюджетов в системе управленческого учета дает возможность повышать качество текущего и стратегического планирования на предприятии, делать его эффективным элементом системы управления.

Ключевые слова: бюджетирование, промышленное предприятие, бюджет, управленческий учет, планирование, сбалансированная система показателей, стратегические цели, стратегическое бюджетирование.

Received by the editors: 23.10 .2020

and final form 29.12.2020 